InOedia $\quad \begin{aligned} & \text { InMedia } \\ & \text { The French Journal of Media Studies }\end{aligned}$

$2 \mid 2012$

Performing/Representing Male Bonds

\title{
Cinema and the Crossing of Frontiers, 16th SERCIA Conference
}

8-10 September 2011, University of Bath

Julie Assouly et Marianne Kac-Vergne

\section{OpenEdition}

\section{Journals}

Édition électronique

URL : http://journals.openedition.org/inmedia/480

DOI : 10.4000/inmedia.480

ISSN : 2259-4728

Éditeur

Center for Research on the English-Speaking World (CREW)

Référence électronique

Julie Assouly et Marianne Kac-Vergne, "Cinema and the Crossing of Frontiers, 16th SERCIA

Conference », InMedia [En ligne], 2 | 2012, mis en ligne le 05 décembre 2012, consulté le 08 septembre 2020. URL : http://journals.openedition.org/inmedia/480 ; DOI : https://doi.org/10.4000/inmedia.480

Ce document a été généré automatiquement le 8 septembre 2020

(c) InMedia 


\title{
Cinema and the Crossing of Frontiers, 16th SERCIA Conference
}

\author{
8-10 September 2011, University of Bath \\ Julie Assouly et Marianne Kac-Vergne
}

\section{NOTE DE L'ÉDITEUR}

Conference organized by Wendy Everett, Nina Parish, Peter Wagstaff and Melvyn

Stokes

1 The SERCIA (Société d'Etudes et de Recherche sur le Cinéma Anglophone), founded in 1993 to gather researchers of English-speaking film and to promote their work, held its $16^{\text {th }}$ conference in September 2011 at the University of Bath. The conference was organized by Wendy Everett, Reader in French and Film at the University of Bath, Nina Parish, Lecturer in Contemporary French Studies at the University of Bath, Peter Wagstaff, Senior Lecturer in French at the University of Bath, and Melvyn Stokes, Senior Lecturer in American Film History at University College London.

2 The theme of the conference was "Cinema and the Crossing of Frontiers", an open invitation to probe the adventurous spirit of cinema, its desire to create and explore new territories and technologies in its quest for modernity. Indeed, the theme invited very diverse points of view as well as different research methodologies - from historical approaches to geographical standpoints, including sociological and aesthetic perspectives.

3 There were 24 panels of three or four speakers, organized in 8 sessions. ${ }^{1}$ The plenary was given by film director Ken Loach, who spoke about the three frontiers he had to cross to make his films: moving from the small screen to the big screen, breaking taboos "to say the unsayable", on Ireland or 9/11 for example, and lastly getting his films distributed, especially in the US market. Indeed, whereas films in the US market are often considered as commodities, Ken Loach holds true to his vision of film as a means of communication and to his desire to widen the range of movies offered to the 
audience. His speech provided a practical application of the conference's theme while engaging with the political considerations which characterise his work.

Politics were also discussed in the two panels on the US-Mexico border which included a paper by Stephanie Fuller (University of East Anglia) on 'Borderline identity', an examination by Anne Crémieux (Université Paris Ouest Nanterre La Défense) of the cinematic crossings of frontiers in Babel, an analysis by Rosa Urtiaga (Universite de Zaragoza) of the Chicana in John Sayles's Lone Star and a presentation by Jeffrey Swartwood (Université Bordeaux 3) on The Gatekeeper by the relatively unknown Mexican-American filmmaker/activist John Carlos Frey, whose films have never been distributed in France. All stressed the link made by the films between crossing the border and changing identities, yet one could detect through the different presentations a general evolution from the time of Borderline (1950), when Chicano and Chicana actors played a variety of ethnic characters, to the late 1990s and early 2000s, when Mexican-American identity became the central subject of films such as Lone Star (1996) or The Gatekeeper (2002).

5 Another geographical border was the theme of the panel "Crossing the Atlantic" where two presentations caught our attention, both adopting a historical perspective on film and reception. Melvin Stokes (University College London) spoke about Charlie Chaplin's links with the French surrealists, who drew inspiration from his films and came together in his defense in the 1927 manifesto Hands Off Love, using him as "a symbol with which to further their own outlook and ideas." Nimrod Tal (Oxford) analyzed how the different cultural contexts influenced the reception of Birth of a Nation and Gone with the Wind in the United States and Great Britain. While Birth of a Nation was seen in Britain as an exotic American product about the Civil War, without full recognition of its controversial racial dimension, Gone with the Wind was received with more ambiguity because of its antiwar message (the movie was released during the Second World War) and its gender and racial representations.

The issue of identity as a fluid and permeable construction was at the heart of a panel on Multiple Identities, where two of Woody Allen's films were analyzed - Isabelle Schmitt (Université de Bourgogne) examined the crossing into another woman's psyche in Another Woman, while Ana Moya (Universitat de Barcelona) revealed the transnational dimension of Vicky Cristina Barcelona, emphasizing the difficulty for the characters to preserve their cultural identities. Her analysis brought her to reconsider the notion of transnationalism as the reflection of the characters' state of mind. The central threesome is constantly on the verge of breaking down, symbolically crossing the boundary from one self to another out of dissatisfaction (the way one would cross the border between two continents in search of a new life). To a certain extent, the recurring use of unsubtle clichés (the Spanish virile male, the spicy Spanish woman, the naïve American girl, the romanticized artistic life...) can be seen as another implicit commentary on the futility of holding onto them.

Gender and racial identities were also the subject of Anne-Marie Paquet-Deyris's (Université Paris Ouest Nanterre) presentation on Imitation of Life, which focused on the notions of passing and trespassing in melodrama and the subversion of stereotypes to foreground the issue of racial legitimacy. Examining the crossing of racial and social borders in the two versions of the film was a way for Pr Paquet-Deyris to reevaluate the melodramatic genre, as Sirk's film broke some of the genre's conventions by addressing the burning question of black self-loathing. Yet she concluded her presentation by 
pointing out the difficulty for both black and white spectators to identify with the characters and situations, as they often remain, even in Sirk's version, quite stereotypical.

From an aesthetic perspective, an interesting debate was engaged in a panel about "Crossing the Boundary between Fiction and Documentary". Jean-Francois Baillon (Université Bordeaux 3) chose to discuss Powell and Pressburger's wartime feature films, while Christophe Gelly (Université Clermont-Ferrand 2) commented on the hybrid nature of Lost in La Mancha by Terry Gilliam, a production which never became an actual movie, maintaining "an ambiguous status mixing reality and fiction and adopting a self-conscious mode of representation". Furthering this discussion on aesthetic hybridity, Barbara Le Maitre (Paris 3) analyzed the work of photographer Jeff Wall, who used the conventions of zombie movies to stage fake historical photographs. Developing her previous essay on aesthetics, Entre film et photographie. Essai sur l'empreinte (Presses Universitaires de Vincennes, 2004), the French researcher chose to put forward Ephraim Getthold Lessing's theory of the 'pregnant moment', the possible link between still and moving images. Practicing what Le Maitre called a "remelting of the media" thanks to a digital photomontage, Wall built an artificial battlefield on which each soldier seems to come back to life in spite of a deadly wound, recalling Romero's horror films. Zombie movies were also the focus of a Foucauldian analysis of subjection and subjectivity in David Roche's (Université de Bourgogne) presentation on George Romero's Living Dead trilogy, while Gilles Menegaldo (Université de Poitiers) considered the generic hybridity of contemporary gothic/horror cinema, in a panel on "Reinventing the Horror Genre".

9 Many other aspects of the question were also addressed, such as the position of the spectator, in a paper given by Céline Murillo (Paris 13) on the redefinition of screen borders in Jim Jarmusch's cinema and in a presentation by Fabrice Lyczba (Université Paris Est Créteil) on publicity and exhibition practices of American silent cinema. Technological crossovers, the western frontier, generic hybridity, globalization and national borders were also developed, making this conference a rich and stimulating event.

10 The following, 17th SERCIA conference, entitled "Cinema of intimacy and/or the intimacy of cinema in English-speaking film", took place in Dijon from September 5 to September 7, 2012. More information can be found on the SERCIA website (www.sercia.net).

\section{NOTES}

1. Due to the very large number of panels, not all of them could be covered in this report. 


\section{AUTEURS}

\section{JULIE ASSOULY}

Université d'Artois

MARIANNE KAC-VERGNE

Université de Picardie Jules Verne 